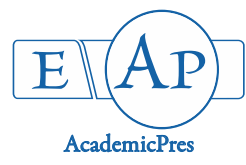

\title{
Impact of Media on Air-layering in the Propagation of Dennettia tripetala (Annonaceae), and Its Micro-morphological Characteristics
}

\author{
Fred Bayo YAKUBU ${ }^{1}$, Emmanuel Chukwudi CHUKWUMA ${ }^{2 *}$, \\ Elizabeth Adetutu AWOSAN ${ }^{1}$ \\ ${ }^{1}$ Department of Sustainable Forest Management, Forestry Research Institute of Nigeria, PMB 5054, Ibadan, \\ Nigeria; fredyakubu@yahoo.com; funmitutu@yahoo.com \\ ${ }^{2}$ Forest Herbarium Ibadan (FHI), Department of Forest Conservation and Protection, Forestry Research Institute of Nigeria, PMB 5054, \\ Ibadan, Nigeria; chukwuma.ec@frin.gov.ng; ("corresponding author)
}

\begin{abstract}
A systematic study was carried out on Dennettia tripetala to establish an alternative method of propagation and further provide complementary characters for the identification of the species especially in sterile conditions. All methods followed those of previous authors of related studies. Findings from the silvicultural aspect revealed that it is very possible to successfully propagate the species via air-layering, using good quality materials. Top soil performed better than saw dust substrate. The roots appeared and developed much faster than those of the saw dust, before it was harvested and potted. Micromorphological examination of the foliar epidermises also showed that the species is hypostomatic, while epidermal cells are predominantly polygonal, measuring $37.1 \times 22.0 \mu \mathrm{m}$ and $30.4 \times 15.4 \mu \mathrm{m}$ in size on the abaxial and adaxial surfaces respectively, and with straight to sinose anticlinal walls. Stomata is anomocytic, up to $32.2 \times 17.6 \mu \mathrm{m}$ in size. Wood is vesseless with tyloses present and gums totally absent. Ray multiserate. Pollen grains are predominantly spheroidal with scabrate surface and thin exine. Further studies on other aspects may reveal more useful information about $D$. tripetala.
\end{abstract}

Keywords: conservation; Dennettia; propagation; silviculture; taxonomy

\section{Introduction}

Plants have remained integral sources of food and nutrients for both humans and animals. We simply cannot survive without them. These plants contain several chemical compounds essential for the metabolic functioning of our body systems (Achinewhu et al., 1995). Dennettia tripetala Bak., family (Annonaceae) is a small tree of the rain-forest and occasionally in the savanna, growing up to $18 \mathrm{~m}$ and about $60 \mathrm{~cm}$ in girth. Branchless glabrous, leaves oblong or oblong-elliptic, very shortly cuneate at base, obtusely acuminate, about $10-15 \mathrm{~cm}$ long and 4-6 cm wide (Hutchinson and Dalziel, 1954; Burkill, 1985; Keay, 1989). It has a limited distribution in Ivory Coast, Southern Nigeria and Western Cameroons (Burkill, 1985); but in recent times, it has been widely domesticated in the Southern, Eastern and Western parts of Nigeria. It is well known as umimi by the Igbo people of Nigeria, Ata Igebere or igberi by the Yorubas, Imako by the Niger Deltas and Urhobo, ako by Bini, Nkarika by the Efik and Ibibio
(Burkill, 1985; Gbile and Soladoye, 2002). The wood is white, soft and not durable, and is susceptible to termites. Bark is fibrous and strongly scented. The young leaves are chewed on account of their pungent spicy taste. The fruits, green at first then turning red, ripen in April and May have a peppery spicy taste and are chewed for this property (Keay, 1989). Okiy (1960) reported that the fruit is regarded as a good source of vitamin.

Studies have shown that $D$. tripetala contains calcium, iron, magnesium, zinc, manganese and copper while the fruit primarily contains minerals, vitamins, oils, iron flavours (Okafor, 1980), crude proteins, fibre, ash, carbohydrate, sulphur (Okafor, 1980, Udoessian and Ifon, 1984; Okwu and Morah, 2004). The leaves have been reported to be useful in treatment of cough, asthma, catarrh, toothache, diarrhoea and rheumatism; and also combined with mango leaves for the treatment of mild (Nwinuka and Nwiloh, 2009). Studies by Ejechi and Akpomedaye (2005) also showed that the fruits of $D$. tripetala contain an essential oil which has been used as an effective preservative for stored grains such as cowpea and maize without negatively affecting their viability. 
D. tripetala has inconsistent fruiting, poor seed germination and slow seedling growth. However, there is a high demand of its fruit due to its various uses, and hence the species has been rendered threatened in its natural habitat. The seed is the only alternative for its inexpensive propagation. There is dearth information on it macropropagation. This study thus focuses on the macropropagation of this important species, through airlayering in order to achieve an inexpensive domestication and to ensure its continuous availability for human utilization. It also examines the micro-morphological characteristics of the leaf, stem and pollen grain in an attempt to provide additional taxonomic characters for its identification.

\section{Materials and Methods}

\section{Marcottpreparation and setting}

A fifteen years physiologically matured tree of Dennettia tripetala at Eleyele water works in Ibadan metropolis (Latitude $7.4133^{\circ} \mathrm{N}$ and Longitude $3.8630^{\circ} \mathrm{E}$, mean maximum temperature is $26.46^{\circ} \mathrm{C}$, minimum $21.42^{\circ} \mathrm{C}$ and the relative humidity is $74.55 \%$ ) was air-layered using two media (top soil and saw dust). The uniformly sized, selected branches of $12.50 \mathrm{~cm}$ (girth) wrapped were left until sufficient roots were visible through the transparent sheet. As soon as roots grow through the ball of moss, such stem was severed using a saw below the girdled area and the plastic sheet was then removed. The marcotts were taken to the nursery and transplanted into polypots filled with top soil for further growth assessment. These seedlings were watered daily.

\section{Data collection}

The growth assessment was carried out in Multipurpose Tree Species Multiplication Unit Nursery at Forestry Research Institute of Nigeria (FRIN) located on latitude $7.383333^{\circ} \mathrm{N}$ and longitude $3.85^{\circ} \mathrm{E}$ with the main total rainfall of $1548.9 \mathrm{~mm}$ falling in approximately 90 days. The mean maximum temperature is $34^{\circ} \mathrm{C}$, minimum $24.2{ }^{\circ} \mathrm{C}$ and the relative humidity is $71.9 \%$ (Ariwado et al., 2017).

The marcotts were allowed to stabilize for four weeks after which the seedlings were assessed for the number of leaves, height and collar diameter.

\section{Statistical analysis}

Data were analysed by analysis of variance (ANOVA). Standard error was used to separate means.

\section{Micro-morphological studies}

Fresh specimens of the leaves and stem obtained from the same site of marcott preparation were used for this purpose.

\section{Foliar anatomy}

$2-5 \mathrm{~cm}^{2}$ of the leaves were cut and soaked in well covered glass petri-dishes containing concentrated trioxonitrate $(\mathrm{v})$ acid $\left(\mathrm{HNO}_{3}\right)$, for about two hours to macerate the mesophyll. Upon the disintegration of tissues and indication of bubbles, the specimens were carefully transferred unto clean petri-dish and rinsed thoroughly with distilled water before the epidermises were separated using forceps. Tissue debris was carefully cleared off the epidermises with fine Carmel hair brush, and the isolated epidermal layers were adequately rinsed in water. The epidermises were then transferred into another Petri dish containing $50 \%$ ethanol for $1-2$ minutes, thereby allowing hardening of cells. Afterwards, tissues were stained with Safranin $\mathrm{O}$ for five minutes and then rinsed again in distilled water to remove excess stain. They were mounted in $25 \%$ glycerol on clear microscopic glass slides, covered with cover-slips and the edges of the cover slip were ringed with nail varnish to prevent dehydration. Five slides were prepared each for the abaxial and adaxial surfaces of the species, and studied carefully under Olympus light microscope. However, methods followed those of Radford et al. (1974), Adedeji (2004), Chukwuma et al. (2014), and Chukwuma et al. (2017) for leaf epidermal descriptions and Carpentar (2005) for stomata architecture.

\section{Stem anatomy}

Fresh stem of Dennettia tripetala was used for this purpose. The transverse, radial and tangential longitudinal sections were carefully cut at 10 microns using a sledge microtome at the Department of Forest Products Development and Utilization, Forestry Research Institute of Nigeria, Ibadan, Nigeria, following standard procedures. Sections were carefully stained and mounted in DPX mountant, on clear microscopic glass slides and appropriately labelled (Oladipo and Oyaniran, 2013). The mounted specimens were viewed under Olympus light microscope and observations were carefully recorded. Photomicrographic images were also taken with a Scope image 9.0 enabled camera attached to the microscope. All wood anatomical descriptions follow IAWA (1989).

\section{Pollen morphology}

Flowers were subjected to pollen analysis using acetolysis method as described by Ertdman (1960). Pollen was described in accordance with Sowunmi $(1973,1995)$ while shapes and classes were studied and described following Erdtman (1943).

\section{Results and Discussion}

Distributional information sourced from the Forest Herbarium Ibadan (FHI) and University of Ibadan Herbarium (UIH), revealed that the species is confined to the rain-forests of southern Nigeria, extending from IjebuOde in the west to Cross-river in the south. This is an indication that it may not survive in drier parts, hence requiring adequate moisture for optimum growth and productivity (Fig. 1). This distrubution pattern had earlier been reported by Keay (1989) and Ayodele and Yang (2012) who noted that the species is typically a forest taxon.

Interaction effect of top soil on collar diameter, height and number of leaves of Dennettia tripetala

Analysis of variance showed the interaction effects of top soil on collar diameter, height and number of leaves of air layered Dennettia tripetala cuttings. It was observed that interaction of top soil had significant effect on all the 
394

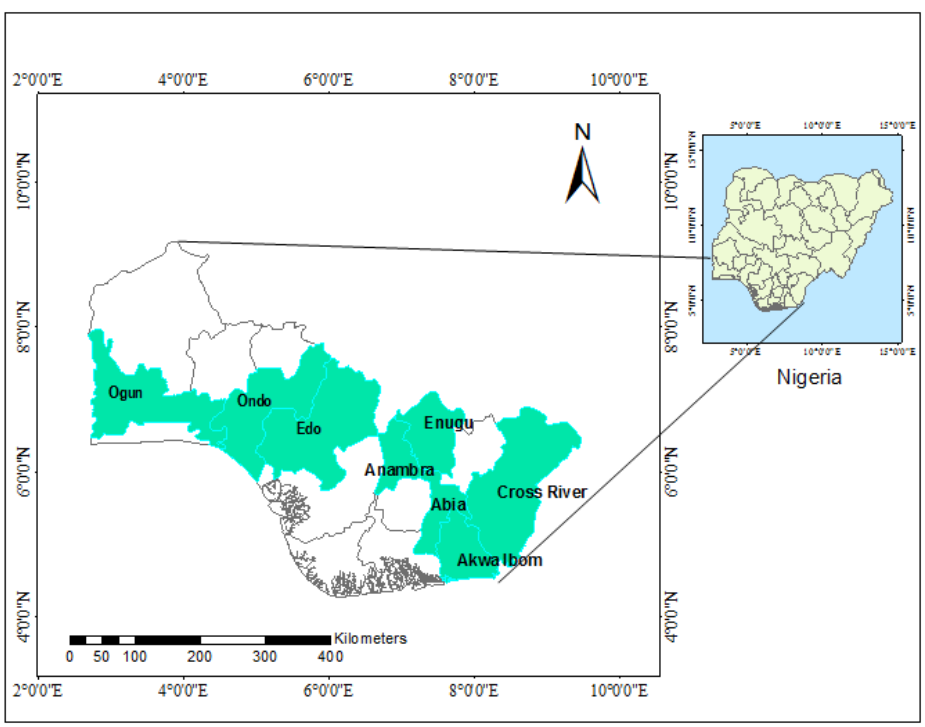

Fig. 1. Map of Southern Nigeria showing distribution of D. tripetala

parameters at 0.05 probability level (Table 1). Mean separation showed that collar diameter had the highest value in the month of March for marcotted cuttings from top soil substrate $(11.2 \pm 0.5 \mathrm{~cm})$ and the least value in the month of May $(7.6 \pm 0.7 \mathrm{~cm})$. Furthermore, height was highest in month May $(62.5 \mathrm{~cm})$ for marcotted plant from top soil and least in the month of March $(55.4 \mathrm{~cm})$. Number of leaves was highest in the month of May (33) for marcoted plant from top soil and least in February. Number of leaves was highest in the month of May $(33 \pm 11.6)$ for marcotted plant from top soil and least in February $(30 \pm 9.1)$.

Interaction effect of saw dust on collar diameter, height and number of leaves of Dennettia tripetala

The effect of interaction of saw dust on collar diameter, height and number of leaves of air layered Dennettia tripetala was also investigated. From the result of analysis of variance, interaction of saw dust had significant effect on all the parameters of air layered Dennettia tripetala at 0.05 level of probability (Table 2).
Collar diameter was highest in the month of April (7.9 \pm 0.7 ) for marcotted plant from saw dust and least in the month of May $(6.8 \pm 1.2 \mathrm{~mm})$. From the result of interaction of saw dust substrate, height had the least mean value in the month of February $(52.0 \pm 3.2 \mathrm{~mm})$ and highest mean value in the month of May for marcotted plant from saw dust substrate $(63.0 \pm 4.0 \mathrm{~mm})$. Number of leaves was highest in the month February $(7 \pm 1.2 \mathrm{~mm})$ and least in the month may for marcotted plant from saw dust $(3 \pm 0.0 \mathrm{~mm})$.

Effect of top soil and saw dust substrate across the growth parameters percentage

Collar diameter had the highest and lowest percentage $18 \%$ and $17 \%$ in the months March and May from top soil substrate respectively. Results from saw dust substrate reveals that in the months of February and March both have the same percent value of $12 \%$ while it was highest in the month April with percent value of $13 \%$ but lowest in May with percent value of $11 \%$.

Table 1. Analysis of variance (ANOVA) of air layered $D$. tripetala seedlings

\begin{tabular}{cccccc}
\hline Source & DF & SS & MS & F-Value & P-Value \\
\hline Factor & 2 & 1348 & 6739.90 & 99.63 & 0.000 \\
Error & 21 & 1421 & 67.95 & & \\
Total & 23 & 14900 & & & \\
\hline
\end{tabular}

Table 2. Growth parameters of $D$. tripetala under the interaction effect of top soil and saw dust substrates

\begin{tabular}{cccc}
\hline Sample & Collar diameter & Height & No. of leaves \\
\hline A1 & $8.1 \pm 0.6$ & $60.1 \pm 3.4$ & $30 \pm 9.1$ \\
A2 & $7.2 \pm 0.4$ & $52.0 \pm 3.2$ & $7 \pm 1.2$ \\
B1 & $11.2 \pm 0.5$ & $55.4 \pm 3.8$ & No data \\
B2 & $7.2 \pm 0.3$ & $59.2 \pm 3.9$ & No data \\
C1 & $8.6 \pm 0.4$ & $61.2 \pm 5.1$ & No data \\
C2 & $7.9 \pm 0.7$ & $58.9 \pm 4.5$ & $4 \pm 0$ \\
D1 & $7.6 \pm 0.7$ & $62.5 \pm 7.5$ & $33 \pm 11.6$ \\
D2 & $6.8 \pm 1.2$ & $63.0 \pm 4.0$ & $3 \pm 0.0$ \\
\hline
\end{tabular}

Key to samples: A - February, B- March, C- April, D- May

1-Top soil, 2- saw dust

(mean \pm standard error 
As showed in Fig. 2, result revealed that there was a decrease in height in month of February (13\%) to March (12\%) and later stabilised from April to May (13\%) in top soil substrate. As for saw dust substrate, highest percent value was evident in month May (14\%) and was least in February $(11 \%)$. There is a constant value from the second and third months which later increased in the last month.

The number of had the highest percentage value of $44 \%$ in month of May in top soil substrate and was least in February, as shown in Fig. 1. However, there was a missing value in March and April as leaves were completely absent on the stems. In contrast, percentage value in saw dust substrate was lowest in month of May (4\%) and highest in February with a percentage of $39 \%$ and there was also a missing percent value in March due to same reason as mentioned above (Fig. 2). The month of March experienced senescence due to physiological behaviour of the seedlings as the matured mother tree.

The effect of the different substrate showed that top soil substrate has a very good performance on the air layered seedlings and also across the growth parameters because the highest percentage value was recorded in top soil substrate.

The research findings from silviculatural study gave an edge as compared to all other related studies that has been carried out so far on airlayering of indigenous fruit trees (IFTs). According to literatures, all studies carried out on layering of IFTs stopped at the rooting stage of the marcotted stems on the mother tree. There was no continuous study as regards to the growth assessment of the severed stem from the mother tree. Vegetative propagation of plants is essentially the reproduction of plant material from vegetative organs so that the offspring will contain the exact characteristics of the parent plant with regard to genotypes and health status (Macdonald, 1996). Air layering as a vegetative method captures the attributes of elite trees within genetically diverse wild populations to avoid long, slow process of tree breeding (Tchoundjeu et al., 2006) and promotes a high success rate of propagation (Diane and Elizabeth, 2009). With a success rate of 28.33\% in this study, the ability of $D$. tripetala to multiply by air layering is very high. This is in contrast to what was obtained when compared to Detarium microcarpum with a low success rate (Ricez, 2008). The results of the experiment carried out by Tchoundjeu et al. (2010) showed that auxin treatment decreased the rooting percentage and increased the mortality rate of Irvingia gabonensis marcotts. Several trials of air layering have however given more satisfactory results on other species: Pterocarpus erinaceus Poir. with $100 \%$ success (Zouggari 2008), Balanites aegyptiaca (L.) Del. with a success rate of $95 \%$ (Tchiagam et al., 2011), Cola edulis Baill. with 48\% success (Moupela et al., 2013), and Prunus azorica (Hort. ex Mouillef.) Rivas Mart. with 100\% success in Azores (Moreira et al., 2009).

As a result of the physiological maturity cycle of the plant marcotted, senescence was experienced, leading to the loss of leaves in seedlings. This affected the initial rate of photosynthesis, therefore a reduction in the net assimilation rate (NAR). The material in the vascular bundle reserve, developed new roots which assisted in assimilation of nutrients from the soil. New structures are developed and increase in growth of the marcotted seedlings (Fig. 3).

Table 3. Foliar micro-characters of D. tripetala

\begin{tabular}{ccc}
\hline Micro-characters & Abaxial & Adaxial \\
\hline Stomata type & Anomocytic & Absent \\
Stomata length & $23.2 \pm 1.5$ & Absent \\
Stomata width & $17.6 \pm 1.9$ & Polygonal \\
Cell type & Polygonal & $30.4 \pm 2.6$ \\
Cell length & $37.1 \pm 8.8$ & $15.4 \pm 2.3$ \\
Cell width & $22.0 \pm 5.2$ & $1.8 \pm 0.6$ \\
Cell wall thickness & $1.7 \pm 0.4$ & Straight - sinose \\
Anticlinal wall pattern & Sinose & Present \\
Druces & Present & \\
\hline
\end{tabular}

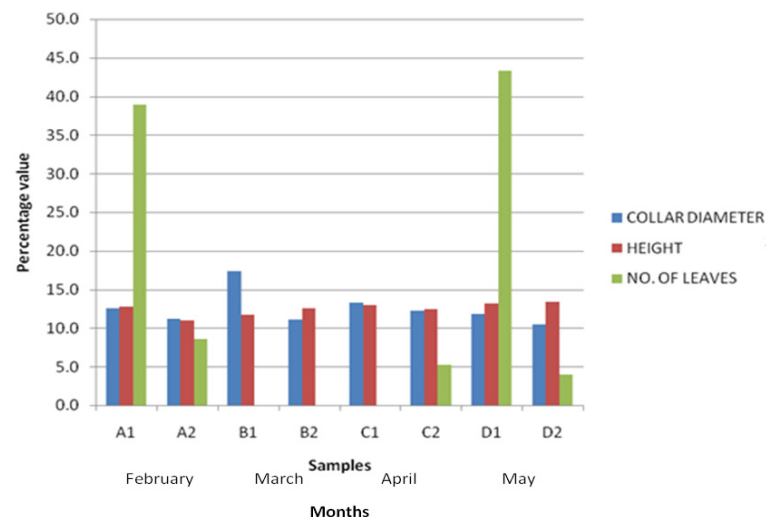

Fig 2. Percentage value of the different substrates across the various growth parameters 
396
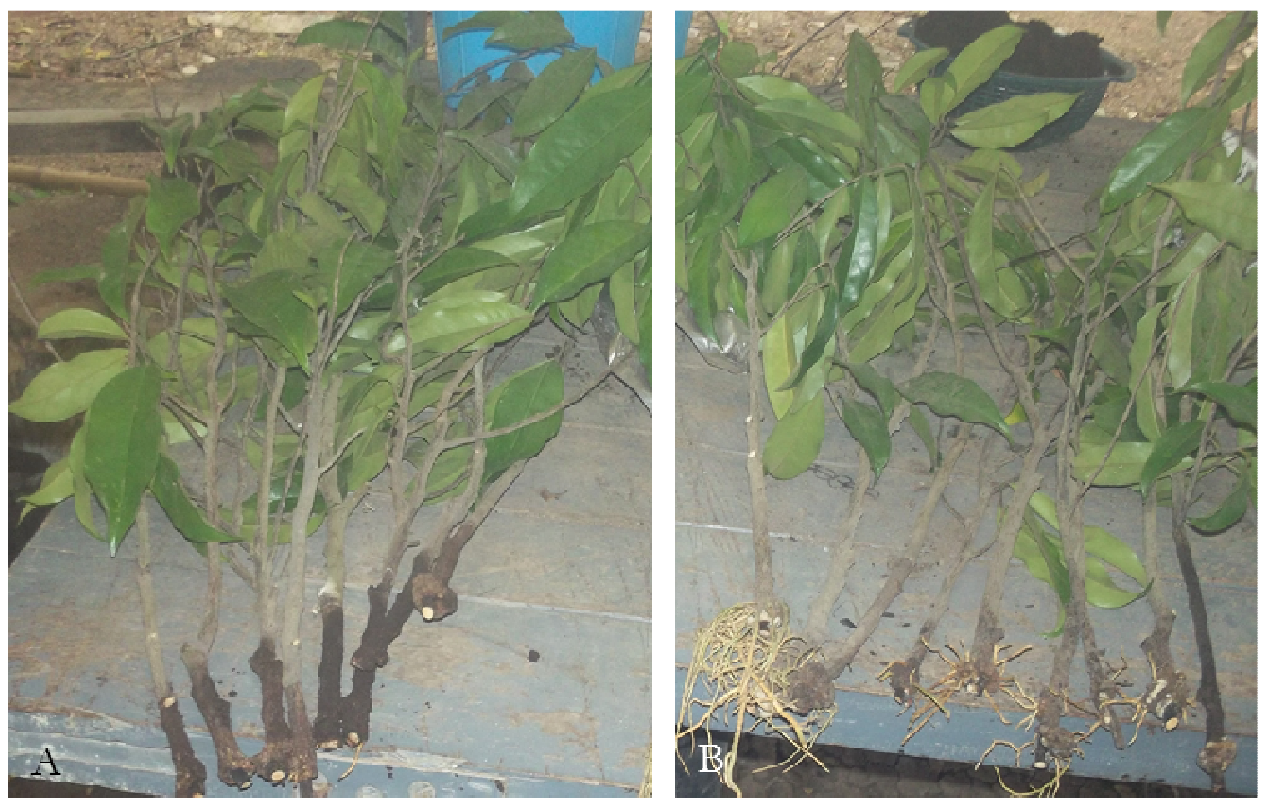

Fig. 3. Rooting system in D. tripetala. A: Air-layering using saw-dust. B: Air-layering using sterilized sharp sand

Further findings from micro-morhological studies of $D$. tripetala showed that the species is hypostomatic, and has some unique characteristics that may be useful for its identification. Folair epidermal cells are predominantly polygonal with straight to sinose anticlinal walls (Plate 1). These cells are larger on the abaxial surface than on the adaxial. They measure up to an avearge of $37.1 \times 22.0 \mu \mathrm{m}$ and $30.4 \times 15.4 \mu \mathrm{m}$ in size on the abaxial and adaxial surfaces respectively. Stomata is anomocytic, up to an average of 32.2 $\mathrm{x} 17.6 \mu \mathrm{m}$ in size on the abaxial surface and completly absent on the adaxial (Table 3). Crystals are also present on both surfaces while trichome is entirely absent. As noted by
Peres-Estrada et al. (2000), plants growing in sun exposed areas tend to have higher trichome densities than those in shady environment. The absence of trichome in $D$. tripetala may thus be attaributed to its habitat. Wood is vesselless, composed only of imperforate tracheary elements and parenchyma; tyloses absent; gums present; fibres thin-thick walled; axial parenchyma rare. Fibre septate; ray multiserate with some associated uniserate cells, $>1 \mathrm{~mm}$ (Plate 2). Pollen grains are in tetrad; acalymmate; prolate rhomboidal in shape. P 55.0-(61.0)-64.4 $\mu \mathrm{m}$; E. 51.0-(58.4)-63.2 $\mu \mathrm{m}$. Exine is generally thin; $2.0-3.0 \mu \mathrm{m}$ thick; surface scabrate (Table 4, Plate 3).
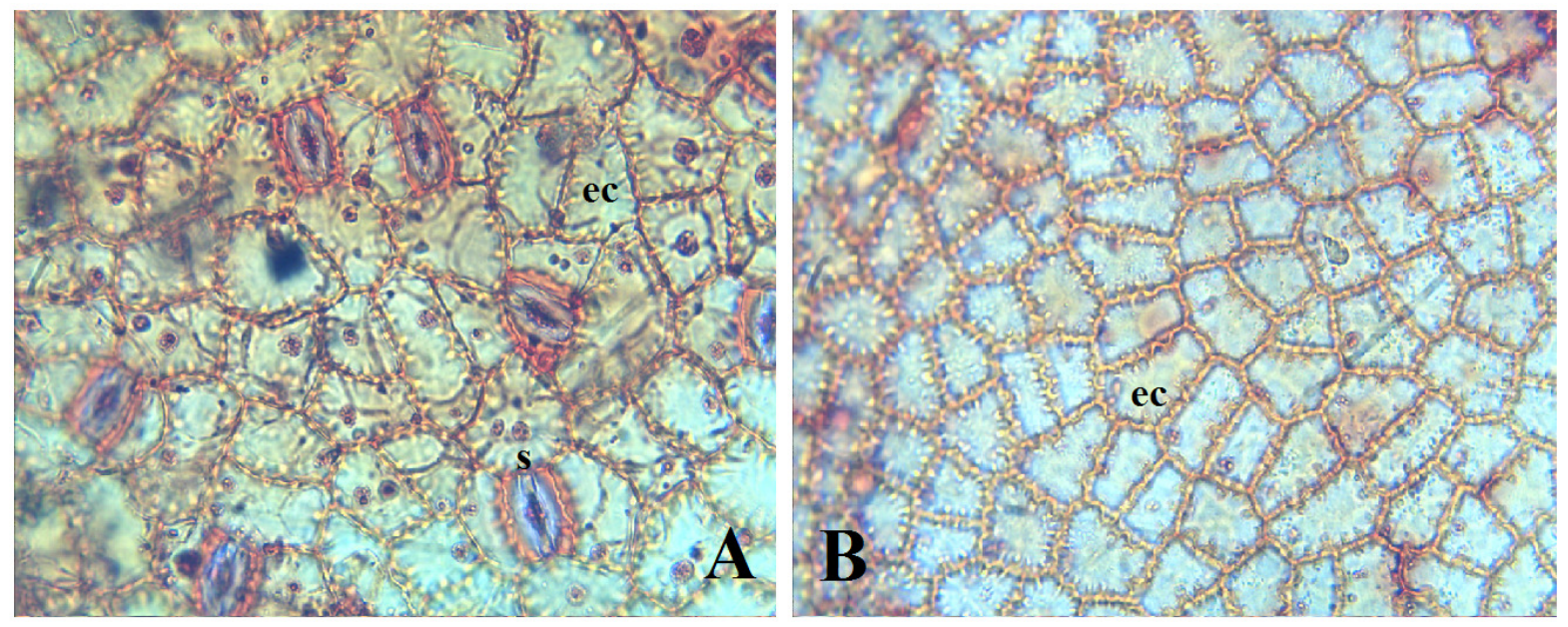

Plate 1. Photomicrographs of the foliar epidermal layers of D. tripetala. X400. A: abaxial surface; B: adaxial surface. ec- epidermal cell; s- stoma 

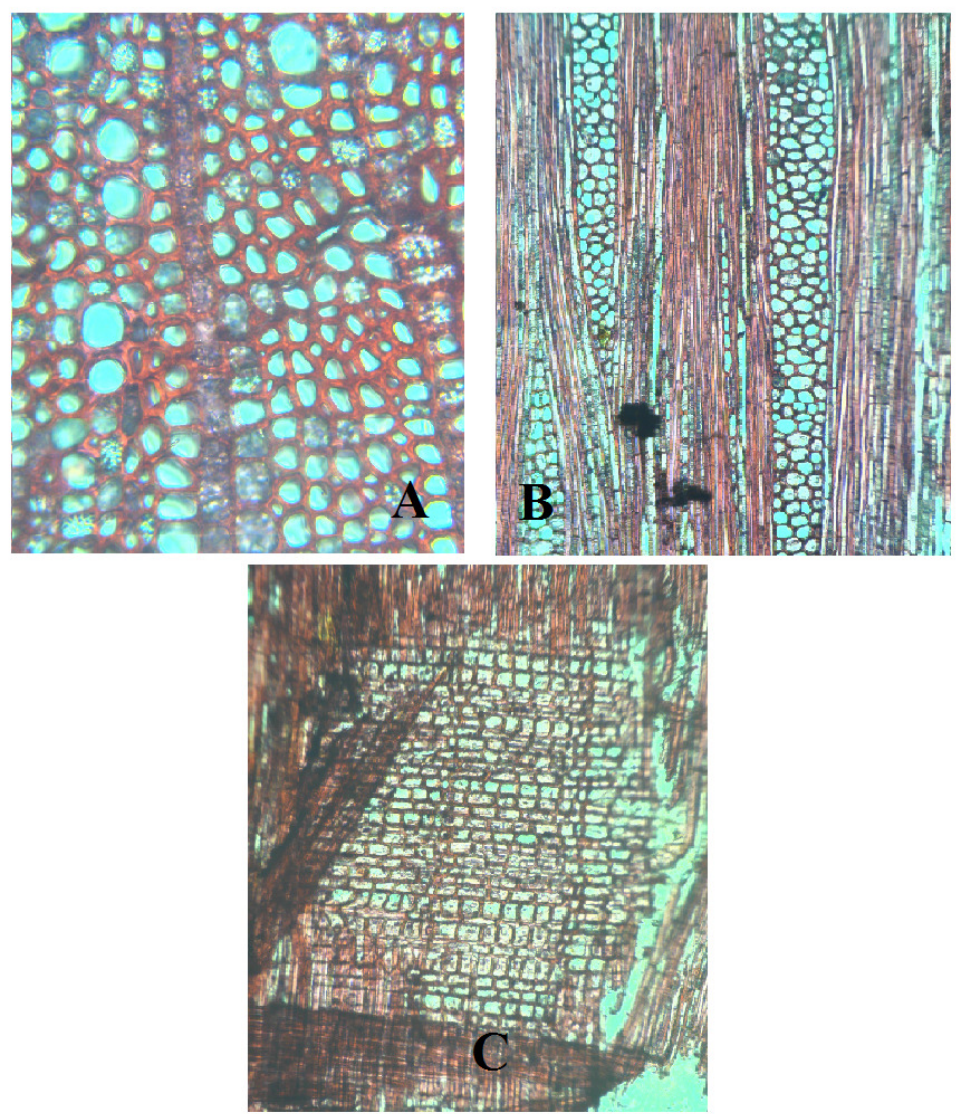

Plate 2. Photomicrographs of the stem of D. tripetala x400. A- transverse section; B-transverse longitudinal section; C- radial longitudinal section

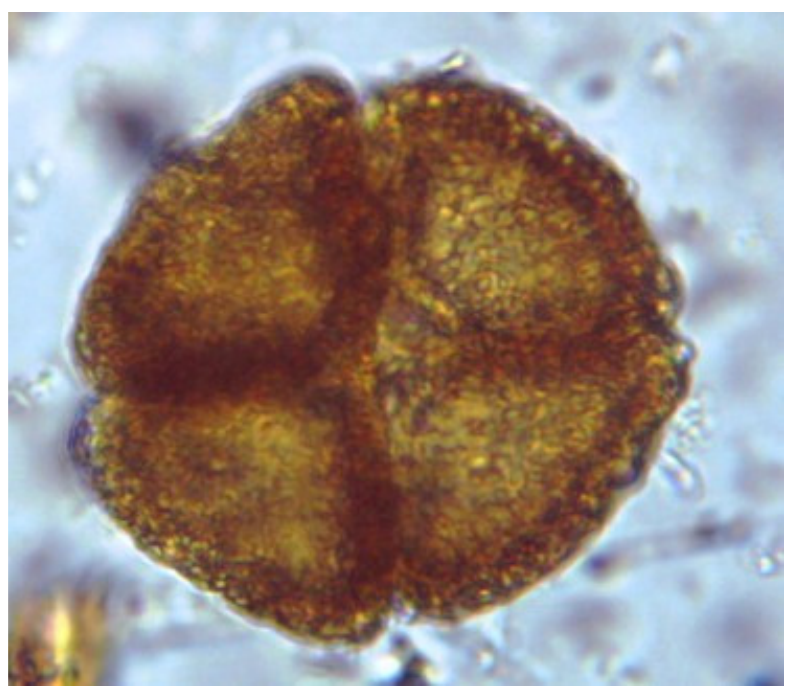

Plate 3. Photomicrograph of D. tripetala pollen X 400

\section{Conclusions}

In the present study, efforts were made to develop an efficient, rapid and inexpensive method for vegetative propagation of Dennettia tripetala. The results indicate that it is possible to successfully propagate pepper fruit by air
Table 4. Pollen characteristics of $D$, tripetala

\begin{tabular}{cc}
\hline Exine thickness $(\mu \mathrm{m})$ & $2.0-3.0$ \\
Polar diameter $(\mu \mathrm{m})$ & $55.0-64.4$ \\
\hline Equatorial diameter $(\mu \mathrm{m})$ & $51.0-63.2$ \\
Shape & Pro-rhomboidal \\
Surface & Scabrate \\
\hline
\end{tabular}

layering. The best growth assessment was obtained from marcotted stem of top soil substrate. The development of rapid and more efficient vegetative propagation techniques for important but neglected indigenous African tropical fruit trees species like the pepper fruit will to a very large extent facilitate the full domestication and fruit production potentials. This would be a very efficient and effective way of combating hunger and by extension, extreme poverty. The present study thus have shown that propagating trees of the species by air layering is possible and this technique can be used to multiply and keep this species, which will reduce the regeneration problem linked to a low seed germination rate and too much demand on the seeds. Dennettia tripetala showed a good aptitude for being propagated by air layering. Morphological studies have also revealed that the species has some interesting characteristics such as presence of cell inclusions/crystals on both surfaces of the leaves, complete absence of trichomes, polymorphic nature of wood rays as wells as the unique shape and sizes of 
398

the pollen grains. Ecological data reported by herbarium collectors showed the spread of this economic species across the forest areas of Nigeria, however, with the continuous degradation of our ecosystems, there is the need for sustainable collection and use of our rich but endangered flora species such as $D$. tripetala to checkmate total disappearance of these important life sustainers.

\section{Conflict of Interest}

The authors declare that there are no conflicts of interest related to this article.

\section{References}

Achinewhu SG, Ogbonna C, Hard AD (1995). Chemical composition of indigenous wild herbs, spices fruits, nuts and leafy vegetables used as food. Plants Foods for Hyman Nutrition 48(4):341-388.

Adedeji O (2004). Leaf epidermal studies of Emilia Cass. (Senecioneae, Asteraceae) in Nigeria. Botanica Lithuanica 10(2):121-133.

Ariwaodo JO, Chukwuma EC, Adeniji KA (2012). Some medicinal plant species of Asamagbe stream bank vegetation, Forestry Research Institute of Nigeria, Ibadan. Ethnobotany Research and Applications 10:541549.

Ayodele AE, Yang Y (2012). Diversity and distribution of vascular plants in Nigeria. Qingdao Publishing House, Chinapp 350.

Burkill HM (1985). The useful plants of west tropical Africa. Vol 1, Families A-D. Royal Botanic Gardens, Kew pp 110-111.

Carpenter KJ (2005). Stomatal architecture and evolution in basal Angiosperms. American Journal of Botany 92(10):1595-1615.

Chukwuma EC, Soladoye MO, Abdus-Salaam KRP (2014). Taxonomic value of the leaf micro-morphology and quantitative phytochemistry of Clitoria ternatea and Centrosema pubescens (Papilionoideae, Fabaceae). Phytologia Balcanica20(1):3-8.

Chukwuma EC, Soyewo LT, Okanlawon TF, Ugbogu OA (2017). Foliar and petiole anatomy of Pterygota (Sterculioideae; Malvaceae) species and their distribution in Nigeria. Anales de Biología 39:103-109.

Diane R, Elizabeth B (2009). Propagation by cuttings, layering and division. College of Agriculture and Life Sciences, Virginia Polytechnic Institute and State University, Blacksburg, Va, USA.

Egharevba HO, Idah EA (2015). Major compounds from the essential oil of the fruit and comparative phytochemical studies of the fruits and leaves of Dennettia tripetala Barker F. found in North Central Nigeria. International Journal of Pharmacognosy and Phytochemical Research 7(6):1262-1266.

Ejechi BO, Akpomedaye DE (2005). Activity of essential oil and phenolic acid extracts of pepper fruit (D. tripetala) against some food borne micro-organism. African Journal of Biotechnology 4(3):258-261.

Erdtman G (1943). An introduction to pollen analysis. Waltham Mass., pp 239.

Erdtman G (1960). The acetolysis method. A revised description. Svensk Botanisk Tidskrift 54:561-564.

Gbile ZO, Soladoye MO (2002). Vernacular names of Nigerian plants. Yoruba ( 2 nd Edition) Forestry Research Institute of Nigeria, Ibadan, pp
101.

Hartmann HT, Kester DE, Davies FT, Geneve RL (2002). Plant propagation: principles and practices. 7th Ed. Prentice Hall Engineering, Cliff,pp 275-551.

Hutchinson J, DalzielJM(1954). Flora of West Tropical Africa. (Vol. 1 Part 2). Crown agents for oversea governments and administrations, Millbank, London pp 50-51.

IAWA (1989). IAWA list of microscopic features for hardwood identification. IAWA Bulletin 10(3):219-332

Keay RWJ (1989).Trees of Nigeria. Oxford University Press, New York pp 24.

Macdonald B (1996). Practical woody plant propagation for nursery growers. Volume 1, Timber Press Inc.

Moreira O, Martins J, Silva L, Moura M (2009). Propagation of the endangered Azorean cherry Prunus azorica using stem cuttings and air layering. Arquipélago Life and MarineSciences 26:9-14.

Moupela C, Doucet JL, Dä̈nou K, Meunier O, Vermeulen C, Beauchêne J (2013). Essais de propagation par semis et marcottage aérien de Coula edulis Baill. et perspectives pour sa domestication. Bois et Forêts des Tropiques 318(4):3-13.

Nwinuka NM, Nwiloh BI (2009). Physio-chemical properties and fatty acid composition of Dennetta tripetala fruit oil (Pepper fruit). Nigerian Journal of Biochemistry and Molecular Biology 24(1):42-46.

Okafor JC (1980). Edible indigenous woody plants in the rural economy of the Nigeria forest zone. Forest Ecology and Management 3:45-55.

Okiy GEO (1960). Indigenous Nigerian food plants. Journal of West African Science Association 6:117-121.

Okwu DE, Morah FN (2004). Mineral and nutritive value of Dennettia tripetala fruits. Fruits 59(6):437-442.

Oladipo OT, Oyaniran AO (2013). Taxonomic study of the wood anatomy of the Genus Ocimum L. in Nigeria. Ife Journal of Science 15(2):295-302.

Perez-Estrada LB, Cano-Santana Z, Oyama K (2000). Variation in leaf trichomes of Wigandia urens: environmental factors and physiological consequences. Tree Physiology 20:629-632.

Radford AE, Dickson WC, Massey JR, Bell CR (1974). Vascular plant systematics. Harper and Row Publishers, New Yorkpp 167-210.

Ricez T (2008). Etudes des modes de régénération à faible coût de Prosopis africana et Detarium microcarpum en forêt classée de Dinderesso. (Master II: Bioressources en Régions Tropicales et Méditerranéennes), Université Paris XII Val-de-Marne, Paris, France.

Sowunmi MA (1973). Pollen grains of Nigerian plants. I. Woody species. Grana 13:145-186.

Sowunmi MA (1995). Pollen grain of Nigerian plants. II. Woody species. Grana34:120-141.

Tchiagam JBN, Ndzié JP, Bellefontaine R, Mapongmetsem PM (2011). Vegetative propagation of Balanites aegyptiaca (L.) Del, Diospyros mespiliformis Hochst. ex. A. Rich. and Sclerocarya birrea (A. Rich.) Hochst. in northern Cameroon. Fruits 66(5):327-341.

Tchoundjeu Z, Alain CT, Asaah E, Anegbeh P (2010). Domestication of Irvingia gabonensis (Aubry) Lecomte by air layering Journal of Horticulture and Forestry 2(7):171-179. 
Tchoundjeu Z, Asaah E, Atangana A (2006). Methods for vegetative propagation: theory. Lecture handout for SII training workshop on Allanblackia domestication. Tech. Rep. ICRAF-WCA/HT, ICRAF, Nairobi, Kenya.

Udoessian EI, Ifon ET (1984). Chemical studies on the unripe and ripe fruits. Food Chemistry 13(4):257-263.
Zouggari A (2008). Etat de la régénération et domestication des espèces ligneuses utilisées dans l'artisanat d'art dans l'ouest et le sud-ouest du Burkina Faso. (Master II: Bioressources en Régions Tropicales et Méditerranéennes), Paris 12 Val de Marne University, Paris, France. 